\title{
ANALISIS KONTRASTIF MORFOLOGI INFLEKSI DALAM BAHASA ARAB DENGAN BAHASA INDONESIA
}

\author{
Mimi Jamilah \\ STAI Bahasa Arab dan Dakwah Masjid Agung Sunan Ampel \\ Surabaya \\ mimi.jamilah@stibada.masa.ac.id
}

\begin{abstract}
Abstrak
Sebagai alat komunikasi bahasa manusia adalah suatu sistem yang bersifat sistematis atau dalam bahasa Arab disebut Tandzim. Dalam fungsinya, morfologi merupakan salah satu aspek kebahasaan. Proses Morfemis merupakan proses pembentukan kata bermorfem jamak baik derivatif maupun inflektif. Infleksi merupakan proses morfemis yang diakibatkan dari proses afiksasi. Kata kata dalam bahasa berfleksi seperti bahasa Arab, bahasa Latin dan juga bahasa Indonesia untuk dapat digunakan didalam kalimat haruslah disesuaikan dulu bentuknya dengan kategori kategori gramatikal yang berlaku dalam bahasa itu. Alat yang digunakanpun juga disesuaikan. Penilitian ini bertujuan untuk menjawab Rumusan masalah yaitu: analisis kontrastif Morfologi infleksi dalam Bahasa Arab dengan bahasa Indonesia. Data penelitian ini dihimpun dari hasil literature- literature dan selanjutnya dianalisis dengan metode analisis deskriptif. Dari hasil penelitian yang dilakukan pada beberapa literature peneliti menganalisis perbandingan morfologi infleksi dalam bahasa Arab dengan bahasa Arab: a). Bahasa Arab lebih kuat terjadi infleksi dibanding dengan bahasa Indonesia, b). Adapula persamaan antara keduanya. Dalam letak afiksasi bahasa Arab dan bahasa Indonesia sama-sama mengalami afiksasi baik dalam prefix, infiks, sufiks, maupun konfiks.
\end{abstract}

Kata kunci: Analisis kontrastif, Morfologi Infleksi 
Mimi Jamilah : Analisis Kontrastif Morfologi Infleksi dalam Bahasa Arab dengan Bahasa Indonesia

\section{ملخص}

كوسيلة للتواصل، اللغة البشرية هي نظام منهجي أو باللغة العربية يطلق عليه

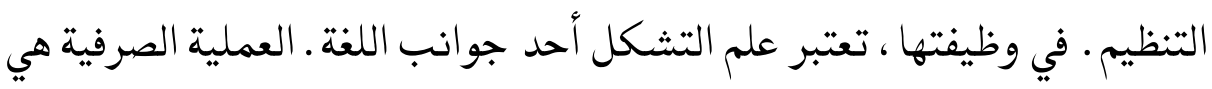
عملية تكوين كلمات صرفية الجمع، سواء المثتقة أو التصريفية. الانعطاف هو

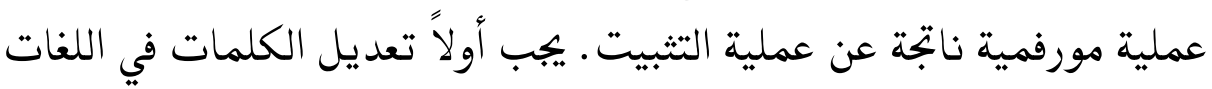
العاكسة مثل العربية واللاتينية والإندونيسية لاستخدامها في جملة من حيث الثكل مع الفئات النحوية المطبقة في تلك اللغة. يتم أيضًا تعديل الأدوات المستخدمة . تهدف هذه الدراسة إلى الإجابة على صياغة المشكلة وهي : التحليل التباين لتشكل الانعطاف باللغة العربية مع الإندونيسية. جمعت بيانات هذا البحث من نتائج الأدبيات ثم تم تحليلها بطريقة التحليل الوصفي. من نتائج البحث الذي تم إجراؤه في العديد من الآداب ، قام الباحث بتحليل مقارنة

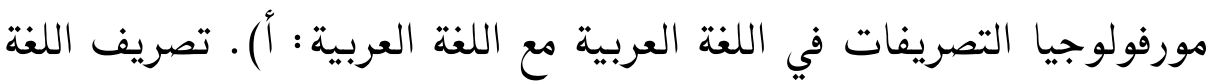
العربية أقوى من الإندونيسية، ب). هناك أيضًا أوجه تثابه بين الاثنين. في موقع اللصق، يختبر كل من اللغتين العربية والإندونيسية عملية التثبيت في كل من البادئة واللاحقة واللاحقة والخلط.

$$
\text { الكلمات المفتاحية : التحليل التقابلي ، مورفولوجيا الانعكاس }
$$

\section{Pendahuluan}

Bahasa adalah alat untuk berfikir, mengekspresikan diri dan berkomunikasi. ketrampilan bahasa sangat penting dalam rangka pembentukan konsep, informasi, dan pemecahan masalah. Melalui bahasa, kita dapat memahami komunikasi pikiran dan perasaan.

\section{IHTIMAM}


Bahasa merupakan system lambing bunyi yang dipergunakan oleh para anggota suatu masyarakat untuk bekerja sama, berinteraksi, dan mengidentifikasi diri. Bahasa merupakan sebuah gabungan dari makna dan bunyi. Bahasa digabungkan oleh tiga buah komponen, yaitu: komponen leksikon, komponen gramatikal, dan komponen fonologi.

Bahasa adalah Asistem lambang bunyi yang bersifat arbitrer, produktif, dinamis, beragam, dan manusiawi ${ }^{72}$ Sebagai sebuah sistem, bahasa pada dasarnya memberi kendala pada penuturnya. Dengan demikian, bahasa pada gilirannya pantas diteliti, karena kendala-kendala yang dihadapi oleh penutur suatu bahasa memerlukaan sebuah pengkajian. Sebagai alat komunikasi bahasa manusia adalah suatu sistem yang bersifat sistematis atau dalam bahasa Arab disebut tandzim. Yang dimaksud dengan sistematis adalah bahwa bahasa itu bukan suatu sistem tunggal, melainkan terdiri dari beberapa subsistem yaitu: fonologi, subsistem morfologi, sintaksis, dan juga semantic.

Salah satu bidang pengkajian bahasa Indonesia yang cukup menarik adalah bidang tata bentukan atau morfologi. Bidang ini menarik untuk dikaji karena perkembangan kata-kata baru yang muncul dalam pemakaian bahasa sering berbenturan dengan kaidah-kaidah yang ada pada bidang tata bentukan ini. Oleh karena itu perlu dikaji ruang lingkup tata bentukan ini agar

72 Chaer, Abdul. 2012, Linguistik Umum, Jakarta : RINEKA CIPTA, hlm.14-18 
Mimi Jamilah : Analisis Kontrastif Morfologi Infleksi dalam Bahasa Arab dengan Bahasa Indonesia

ketidaksesuaian antara kata-kata yang digunakan oleh para pemakai bahasa dengan kaidah tersebut tidak menimbulkan kesalahan sampai pada tataran makna. Jika terjadi kesalahan sampai pada tataran makna, hal itu akan mengganggu komunikasi yang berlangsung. Bila terjadi gangguan pada kegiatan komunikasi maka gugurlah fungsi utama bahasa yaitu sebagai alat komunikasi. Hal ini tidak boleh terjadi.

Dalam fungsinya, morfologi merupakan salah satu aspek kebahasaan. Proses Morfemis merupakan proses pembentukan kata bermorfem jamak baik derivatif maupun inflektif. Infleksi merupakan proses morfemis yang diakibatkan dari proses afiksasi. Kata kata dalam bahasa berfleksi seperti bahasa Arab, bahasa Latin dan juga bahasa Indonesia untuk dapat digunakan didalam kalimat haruslah disesuaikan dulu bentuknya dengan kategori kategori gramatikal yang berlaku dalam bahasa itu. Alat yang digunakanpun juga disesuaikan.

Kasus infleksi ini dalam bahasa Indonesia biasanya hanya terdapat pada pembentukan verba yang disebut dengan verba transitif dan intransitif. Verba transitif artinya kelas kata yang memerlukan suatu objek setelah predikat. Menurut Chaer Prefiks me- untuk verba transitif aktif, prefiks diuntuk verba transitif pasif tindakan, prefiks ter- untuk verba transitif pasif keadaan, dan prefiks zero untuk verba imperatif". Selanjutnya verba intransitif 
artinya kelas kata yang tidak memerlukan objek setelah predikat. ${ }^{73}$ Dalam bahasa Indonesia infleksi verba dicontohkan pada kata kerja dengar ditambah dengan afiks men- menjadi mendengar yang juga termasuk kata kerja dan tidak mengubah kelas katanya. Infleksi verba tidak hanya ditemukan dalam bahasa Indonesia, tetapi juga ditemukan dalam bahasa Arab. Ada beberapa bentuk infleksi yang terjadi bahasa Arab, yaitu: prefix, infiks,sufiks, konfiks. Oleh karena itu untuk menambah pengetahuan dan keilmuwan maka penulis mengambil judul analisis kontrastif morfologi infleksi dalam bahasa Arab dengan bahasa Indonesia.

\section{Pengertian Morfologi Infleksi}

Sebelum kita mengetahui pengertian dari infleksi, alangkah baiknya kita mengetahui apa itu morfologi. Salah satu ahli linguistic menyebutkan bahwa yang dimaksud dengan morfologi dalam bahasa Arab adalah:

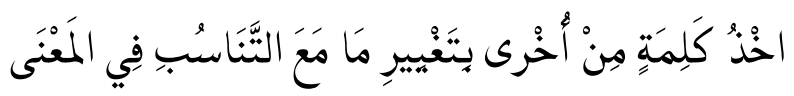

akhżu kalimatin min ukhrā bitagyìri mā, ma`a at-tanāsubi fil ma`nā

“Membentuk kata dari kata yang lain dengan berbagai perubahan, namun tetap memiliki hubungan makna".

Menurut Bickford dkk, dikutif Ba'dulu dan Herman morfologi infleksional tidak mengubah satu kata menjadi kata yang

73Ibid: 38 
Mimi Jamilah : Analisis Kontrastif Morfologi Infleksi dalam Bahasa Arab dengan Bahasa Indonesia

lain dan tidak pernah mengubah kategori sintaksis sebaliknya menghasilkan bentuk lain dari kata yang sama"74 Verhaan berpendapat bahwa morfologi adalah bidang linguistic yang mempelajari susunan bagian kata secara gramatikal. ${ }^{75}$ Menurut Kridalaksana, mengatakan bahwa infleksi adalah perubahan bentuk kata yang menunjukkan berbagai hubungan gramatikal yang mencakup deklinasi nomina, pronomina, ajektiva, dan konjungsi verba, serta merupakan unsur yang ditambahkan oada sebuah kata untuk menunjukkan suatu hubungan gramatikal. ${ }^{76}$

Berdasarkan uraian di atas dapat disimpulkan bahwa infleksi adalah perubahan bentuk kata tanpa mengubah identitas leksikal kata itu dengan atau tanpa mengubah kelas katanya. Secara khusus perubahan bentuk sebuah kata kerja dengan tetap mempertahankan identitas kata kerja itu sama saja artinya dengan mengubah bentuk kata itu, tapi makna kata seperti yang terkandung dalam kata itu tidak berubah.

Morfem adalah satuan bahasa terkecil yang maknanya secara relatif stabil yang tidak dapat lagi dibagi atas bagian makna yang lebih kecil. Proses Morfologis (morphological process) adalah proses yang mengubah leksem menjadi kata. Dalam hal ini leksem

74 Ba'dulu, Abdul Muis dan Herman. 2005. Morfosintaksis. Jakarta: Rineka Cipta, hlm. 5

75Verhaan, J.w.M. 1983. Pengantar Linguistik. Yogyakarta : GADJAH MA DA UNIVERSITY PRESS, hlm. 52

76 Kridalaksana, Harimurti. 2009. Kamus Linguistik. Jakarta: PT Gramedia, hlm. 830 
Mimi Jamilah : Analisis Kontrastif Morfologi Infleksi dalam Bahasa Arab dengan Bahasa Indonesia

adalah input dan kata merupakan output. Proses Morfemis merupakan proses pembentukan kata bermorfem jamak baik derivatif maupun inflektif. Kata " infleksi" berasal dari kata fleksi yang berarti perubahan paradigmatic yang dihasilkan dengan proses morfemis manapun. ${ }^{77}$

Menurut Verhaar, fleksi adalah proses morfemis yang ditetapkan pada kata sebagai unsur leksikal yang sama. ${ }^{78}$ Sedangkan pendapat lain mengatakan bahwa infleksi adalah perubahan bentuk kata yang menunjukkan berbagai hubungan gramatikal yang mencakup deklinasi nomina, pronominal, ejektiva, dan konjungsi verba, serta merupakan unsur yang ditambahkan oleh sebuah kata untuk menunjuk ${ }^{79} \mathrm{kan}$ suatu hubungan gramatikal. ${ }^{80}$ Adapun dalam bukunya khulli mengatakan Infleksi sebagai berikut: 81

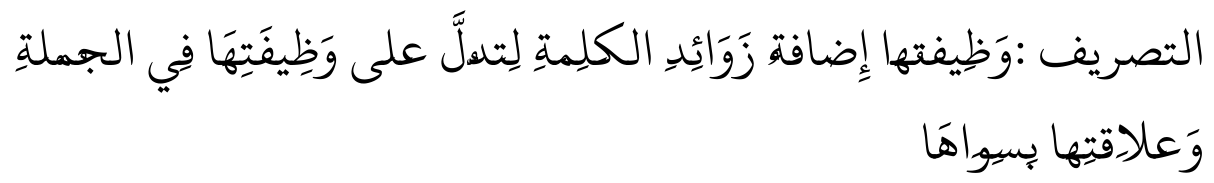

77 J.W.M. Verhar Asas-Asas Linguistik Umum (Yogyakarta: Gajah Mada Press 1990), hlm. 66

78 Ibid, hlm, 177

79 Achmad H.P, Alek Abdullah Linguistik umum (Jakarta: penerbit Erlangga 2013), hlm, 63

${ }^{81}$ Muhammad Ali Al khulli dictionary of theoretical linguistic (libanon: librarie du liban 1982), hlm. 131 
Mimi Jamilah : Analisis Kontrastif Morfologi Infleksi dalam Bahasa Arab dengan Bahasa Indonesia

"Infleksi: menambahkan beberapa huruf tambahan kepada satu kata dengan tujuan merubah fungsinya dalam kalimat dan hubungannya dengan kata-kata yang sebelum dan sesudahnya".

Dari berbagai pengertian diatas bisa kita ambil kesimpulan bahwa yang dimaksud dengan Infleksi adalah proses morfologis yang menghasilkan bentuk kata yang berbeda, namun berasal dari leksem yang sama dan bentukan kata tersebut berada dalam kelas kata yang sama pula. Sebagaimaa yang kita ketahui dalam bahasa arab terdapat tasrif ishtilahi dan Tashrif Lughawy. ${ }^{82}$ Sedangkan infleksi merupakan kategori Tashrif Lughawy. Adapun Infleksi merupakan hubungan kalimat secara Horizontal atau dalam bahasa arab disebut dengan Al Binyah Al- Amiqah, sedangan Derivasi merupakan hubungan kalimat secara Vertical atau yang dikenal dengan Al-Binyah Al-Sathiyyah. ${ }^{83}$

Kata-kata dalam bahasa-bahasa berfleksi, seperti bahasa Arab, bahasa latin,maupun bahasa Indonesia dan bahasa Sansekerta, untuk dapat digunakan dalam kalimat harus disesuaikan dulu bentuknya dengan kategori-kategori gramatikal yang berlaku dalam bahasa itu. Pada umumnya perubahan bentuk atau proses morfologi ini hanya menyatakan hubungan sintaksis dan tidak membawa pemindahan dari satu kelas kata kedalam

82 Musthafa Al-Ghalayani jami' Al-durus Al-Aarabiyah (libanon: AlMaktabah Al-Ashriyah 1972), hlm.75

83 Perkuliahan Matakuliyah Al- Falasafah Al-Lughowiyah UIN SUNAN AMPEL Surabaya 
kelas kata yang lainya. ${ }^{84}$ Dalam pembicaraan diatas tentang Infleksi yang merupakan bagian kecil dari proses Morfemis, atau proses Morfologis atau juga proses Gramatikal, khususnya pembentukan kata dengan afiks. Alat yang digunakan untuk penyesuaian bentuk Infleksi biasanya berupa afiksasi Infleksi berupa:85

1. Prefix (sabiqoh)

Prefix adalah sebuah afiks yang dibubuhkan pada awal kata dasar.

Contoh:

\section{Bahasa Arab}

Kataba- yaktubu

2. Infiks (dakhilah)

Contoh:

\section{Bahasa Arab}

Kataba-kaataba

3. sufiks (lahiqoh)

Contoh:

\section{Bahasa Arab}

Katib-katibah

4. konfiks (aliyah)

Contoh:

\section{bahasa indonesia}

ajar-mengajar

\author{
bahasa Indonesia \\ kerja-kinerja
}

Bahasa Indonesia

tulis-tulisan

${ }^{84}$ Masnur Muslih Tata Bentuk Bahasa Indonesia (Jakarta: Bumi Aksara 2010) , hlm.90

${ }^{85}$ Abdul Chaer Linguistik Umum (jakarta:Rineka Cipta 2007) hlm. 177178 
Mimi Jamilah : Analisis Kontrastif Morfologi Infleksi dalam Bahasa Arab dengan

Bahasa Indonesia

\section{Bahasa Arab}

Kataba-yaktubuuna
Bahasa Indonesia

bersama-kebersamaan

\section{Ciri-Ciri Infleksi}

Perubahan atau penyesuaian bentuk pada verba disebut konjugasi, dan perubahan atau penyesuaian pada nomina dan adjektiva disebut deklinasi. Konyugasi pada verba biasanya berkenaan dengan kala (tense), aspek, modus, diathesis,persona, jumlah, jenis dan kasus. ${ }^{86}$ Dalam buku-buku tata bahasa berfleksi, pembahasan ini biasanya hanya berkisar pada konyugasi dan deklinasi ini saja. Dalam prosesnya, infleksi mempunyai ciri-ciri diantaranya:

1. Menampakkan makna yang teratur atau dapat dirediksikan

2. Bersifat produktif: terdapat pada kaidah umum bila dapat menambahkan afiks infleksional pada salah satu anggota dari sebuah kelas kata.

3. Disusun dalam satu paradigma

4. Cenderung kurang bervariasi, namun dengan distribusi yang luas

5. Biasanya memiliki makna grmatikal

6. Cenderung tidak mengalami pengulangan

86 Sudaryanto, Metode Linguistik (Yogyakarta: Gajah Mada Press, 2002) Hlm. 30

\section{IHTIMAM}




\section{Infleksi dalam Bahasa Arab}

Perubahan atau penyesuaian bentuk pada verba disebut konyugasi, dan perubahan atau penyesuaian pada nomina dan adjektiva disebut deklinasi. Konjungsi pada verba biasanya berkenaan dengan: ${ }^{87}$

1. kala (tense) (madhi-mudhori')

kataba - yaktubu : dia (lk) telah menulis - dia (lk) sedang menulis untuk kala lampau (past) modus indikatif untuk persona yang berbeda

Bentuk kataba akan berubah menjadi:

Orang I tunggal : katabtu $\rightarrow$ aku telah menulis

contoh:

كَتَبْتُ الدَّرْنَ

Saya telah menulis pelajaran

Orang I jamak : katabnaa $\rightarrow$ kami (kita) telah menulis contoh:<smiles>[As]=[As]=[As]</smiles>

Kita/kami telah menulis pelajaran

Orang II tunggal : katabta $\rightarrow$ kamu telah menulis

Contoh:

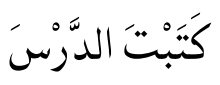

87 Ibid, 170 
Mimi Jamilah : Analisis Kontrastif Morfologi Infleksi dalam Bahasa Arab dengan

Bahasa Indonesia

Kamu (lk) telah menulis

Orang II jamak : katabtum $\rightarrow$ kamu (sekalian) telah

menulis

Contoh:

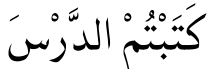

Kalian (lk) telah menulis pelajaran

Orang III tunggal: kataba $\rightarrow$ dia (lk) telah menulis

Contoh:

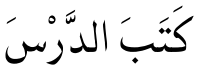

Dia (lk) telah menulis pelajaran

Orang III jamak : katabuu $\rightarrow$ mereka telah mencintai

Contoh:

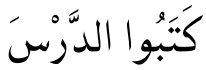

Mereka (lk) telah menulis pelajaran

Sedangkan untuk kala kini (present) modus indikatif untuk persona yang berbeda. Bentuk yaktubu akan berubah menjadi: orang I tunggal : aktubu $\rightarrow$ aku sedang/akan menulis contoh:<smiles>[Si]=[Si][Si]=[Si]</smiles>

Saya sedang menulis surat orang I jamak $\quad$ naktubu $\quad \rightarrow$ kami (kita) sedang/akan menulis

\section{6}


Mimi Jamilah : Analisis Kontrastif Morfologi Infleksi dalam Bahasa Arab dengan

Bahasa Indonesia

contoh:<smiles>[Al]=[Si][Si]#[Si]</smiles>

Kita/kami sedang menulis surat

orang II tunggal : taktubu $\rightarrow$ engkau sedang/akan menulis

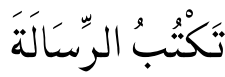

Kamu laki-laki sedang menulis surat

orang II jamak : taktubuuna $\rightarrow$ kamu (sekalian) sedang/akan menulis

contoh:

تَكْتْبُونَ الرِسَِالَةَ

Kamu (sekalian) sedang menulis surat

orang III tunggal : yaktubu $\rightarrow$ dia sedang/akan menulis

contoh:

يَكْتُبْ الرِِّالَة

Dia sedang menulis surat

orang III jamak : yaktubuuna $\rightarrow$ mereka sedang/akan menulis contoh:

يَكْتُبونُ الرَِِّالَةَ

Mereka sedang menulis surat

2. Jumlah ( mujarrod - mazid)

Dlaraba-adlraba :dia (lk) memukul - dia (lk) memukulkan 
Mimi Jamilah : Analisis Kontrastif Morfologi Infleksi dalam Bahasa Arab dengan

Bahasa Indonesia

Contoh:

اَضْرَبَ فَاِيَز الكَلْبَ

Faiz memukulkan anjing

Dlaraba-Tadlaraba : dia (lk) memukul - dia (lk) saling memukul

Contoh:

تَضَارَبَ فَاِيَزْ وَاَحْمَدَ

Faiz dan ahmad saling memukul

3. persona (mudzakar-muaannats)

kataba - katabat : dia (lk) telah menulis - dia (pr) telah menulis

contoh:

كَتَبَ أَحْمَدُ الرَِِِالَة

Ahmad menulis surat-

كَتَبتَتْ فَاطِمَةُ الرِسَِالَةَ

fathimah menulis surat

Pada contoh diatas terjadi proses infleksi, yaitu ada perubahan

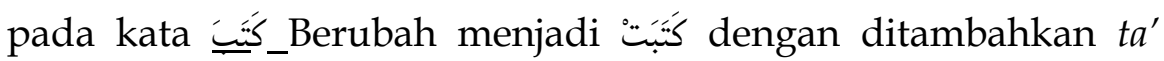
ta'nits dibelakang. Yang mana $t a^{\prime}$ ta'nits merupakan tanda mu'annats (perempuan)

4. Jumlah (mufrod-jama')

Yaktubu - yaktubuuna: dia (lk) telah menulis - mereka (lk) telah menulis

\section{IHTIMAM}


Mimi Jamilah : Analisis Kontrastif Morfologi Infleksi dalam Bahasa Arab dengan

Bahasa Indonesia

Contoh:<smiles>[Al]C[Si]C[Si]</smiles>

Dia laki-laki (1) sedang menulis

يَكْتُبوُونَ الرَِِّالَةَ

mereka sedang menulis

Pَكَتُبْ menjadi ايَكْتُبُنَ dengan menambahkan wawu dan nun dibelakang. Yang mana wawu dan nun merupakan tanda Jama' mudzakar salim (jama' untuk laki-laki)

Adapun Deklinasi atau perubahan bentuk pada kata benda sebagaimana berikut:

1. Jenis ( mudzakar - mu'annats)

Kaatib - kaatibah $\rightarrow$ penulis lk - penulis pr

Contoh:

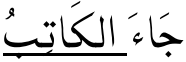

Penulis (lk) itu datang

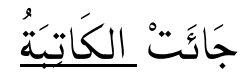

penulis (pr) itu datang 
Mimi Jamilah : Analisis Kontrastif Morfologi Infleksi dalam Bahasa Arab dengan

Bahasa Indonesia

Pada contoh diatas terjadi perubahan dari maskulin - feminism dengan sufiks " ta' marbuthah" sebagai tanda ta'nits atau arti perempuan.

2. Jumlah ( mufrad jamak)

Kaatib - kaatibaani- kaatibuna-katibat $\rightarrow$ penulis $1 \mathrm{lk}(1)$ - penulis pr

(2) penulis lk (banyak)

جَاءء الكَاتِبْ

Seorang penulis (1) itu datang

جَاءَ الكَاتِتَانْ

Dua orang penulis itu datang

جَاءَا الكَاتِبْونَ

Para penulis itu datang

Contoh di atas mengalami perubahan dari segi jumlahnya. Dengan dipasang "alif nun" sebagai tanda tatsniyah (2) "wawu nun " sebagai tanda jama' mudzakar salim (jama' untuk laki-laki) dan "alif $\mathrm{Ta}^{\prime}$ "sebagai tanda jama' mu'annats salim (jama' untuk perempuan

3. Adjektiva (Sifat - superlative)

Karimun - akramu $\rightarrow$ mulya - lebih mulya

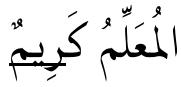

Guru adalah orang yang mulya

\section{IHTIMAM}




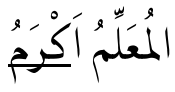

Guru adalah orang yang paling mulya/lebih mulya

Contoh di atas mengalami perubahan dari segi bentuknya, ada ada penambahan huruf "alif" sebagai tanda superlative atau mempunyai makna lebih/paling

\section{Macam-Macam Infleksi dalam Bahasa Indonesia}

Proses pergantian kadangkala disebut pula dengan perubahan dakhil (internal change). Sebuah morfem dasar bebas dapat mengalami perubahan dalam tubuhnya sendiri dengan adanya pergantian salah satu unsure fonemnya baik konsonan, Vokal, maupun ciri-ciri yang lain. Proses ini banyak kita jumpai dalam bahasa Inggris, bahasa Arab maupun bahasa Asing lainya yang mengalami fleksi yan g kuat. Dalam bahasa Indonesia proses ini dikenal pula dalam contoh yang tidak begitu prooduktif. Biasanya kata-kata serapan. ${ }^{88}$ Bentuk bentuk infleksi biasanya memberikan/ menyatakan beberapa kategori ketatabahasaan seperti tunggal jamak, jenis kelamin, waktu, aktif pasif, tata tingkat sifat. Beberapa contoh dalam bahasa Indonesia sebagai berikut:

1. Perubahan pada kalimat Verbal

Kalimat Transitif - kalimat Intransitif

Contoh :

88 Jos Danil Parera, Morfologi Bahasa (Jakarta: Gramedia Pustaka 1994), hlm,19 
Mimi Jamilah : Analisis Kontrastif Morfologi Infleksi dalam Bahasa Arab dengan

Bahasa Indonesia

Membawa-membawakan

Membuka-membukakan

Menambil-mengambilkan

Kalimat aktif-pasif

Contoh:

Melihat-dilihat

Mengantar-diantar

Mengambil-diambilkan

2. Perubahan pada kalimat Nominal

Maskulin-Feminim

Contoh:

Wartawan-wartawati

Karyawan-karyawati

Pemuda-pemudi

Wisudawan-wisudawati

Kata Sifat

Kecil-kekecilan

Besar-kebesaran

Analisis Kontrastif Morfologi Infleksi dalam Bahasa Arab Dengan Bahasa Indonesia

Dari penjelasan di atas dapat kita analisis bahwa dalam proses infleksinya kedua bahasa yaitu bahasa Arab dan bahasa Indonesia memiliki persamaan dan juga perbedaan tentunya.

\section{IHTIMAM}


Karena masing-masing bahasa memiliki sistem atau aturan yang berbeda pula. Begitu juga dengan kedua bahasa tersebut. Mereka memiliki aturan yang berbeda yang berlaku pada pemilik bahasanya. Untuk lebih mudah memahami dan menganalisisnya maka coba kita perhatikan table kontrastif berikut ini:

\begin{tabular}{|c|c|c|c|c|c|}
\hline $\mathrm{N} / \mathrm{V}$ & $\begin{array}{c}\text { Infleksi } \\
\text { Bahasa } \\
\text { Arab }\end{array}$ & Contoh & $\begin{array}{c}\text { Infleksi } \\
\text { Bahasa } \\
\text { Indonesi }\end{array}$ & Contoh & $\begin{array}{l}\text { keteranga } \\
\text { n }\end{array}$ \\
\hline \multirow{4}{*}{ Verbal } & $\begin{array}{l}\text { Madhi - } \\
\text { mudhori' } \\
\text { (kala) }\end{array}$ & $\begin{array}{l}\text { Kataba- } \\
\text { yaktubu }\end{array}$ & & & \\
\hline & $\begin{array}{l}\text { Ma'lum - } \\
\text { majhul }\end{array}$ & $\frac{\text { Kataba- }}{\text { kutiba }}$ & Aktif - pasif & $\begin{array}{l}\text { Menulis - } \\
\text { ditulis }\end{array}$ & \\
\hline & $\begin{array}{l}\text { Mujarrod - } \\
\text { mazid }\end{array}$ & $\begin{array}{l}\text { Kataba- } \\
\text { aktaba }\end{array}$ & $\begin{array}{l}\text { Transitive- } \\
\text { Intransitive }\end{array}$ & $\begin{array}{l}\text { Menulis - } \\
\text { menuliska } \\
n\end{array}$ & \\
\hline & $\begin{array}{l}\text { Mudzakar } \\
\text { muannats }\end{array}$ & $\begin{array}{l}\text { Katabta- } \\
\text { katabti }\end{array}$ & & & \\
\hline \multirow{4}{*}{$\begin{array}{l}\text { Nomin } \\
\text { al }\end{array}$} & $\begin{array}{l}\text { Mufrod - } \\
\text { jama' }\end{array}$ & $\begin{array}{l}\text { Kaatib - } \\
\text { kaatibaan } \\
\text { i katibuna }\end{array}$ & & & \\
\hline & $\begin{array}{l}\text { Mudzakar } \\
- \\
\text { Mu'annats }\end{array}$ & $\begin{array}{l}\text { Katib- } \\
\text { katibah }\end{array}$ & $\begin{array}{l}\text { Maskulin - } \\
\text { feminism }\end{array}$ & $\begin{array}{l}\text { Wartawan } \\
= \\
\text { wartawati }\end{array}$ & \\
\hline & \multirow{2}{*}{$\begin{array}{l}\text { Sifat - isim } \\
\text { tafdhil }\end{array}$} & \multirow{2}{*}{$\begin{array}{l}\text { Karama- } \\
\text { akroma }\end{array}$} & \multirow{2}{*}{$\begin{array}{l}\text { Sifat - } \\
\text { superlative }\end{array}$} & Besar & \\
\hline & & & & Kebesaran & \\
\hline
\end{tabular}


Mimi Jamilah : Analisis Kontrastif Morfologi Infleksi dalam Bahasa Arab dengan Bahasa Indonesia

Tabel di atas menunjukkan bahwa proses infleksi dalam bahasa Arab lebih kuat dibanding dengan bahasa Indonesia. Terbukti pada contoh kalimat Verbal bahasa Indonesia hanya mengalami infleksi pada kalimat aktif pasif dan mujarrad mazid saja. Sedangkan pada contoh kalimat nomina bahasa Indonesia mengalami beberapa bentuk perubahan akan tetapi tidak banyak mengalami proses infleksi.seperti yang terdapat dalam contoh wartawan-wartawati dan kebesaran Sedangkan yang lainya mengalami proses morfemis akan tetapi tidak termasuk infleksi. Karena infleksi merupakan akibat yang ditimbulkan dari afiksasi itu sendiri. Akan tetapi dari perbedaan-perbedaan infleksi yang ada. Tentu ada persamaan dalam proses infleksi ditinjau dari letak afiksasi. Untuk lebih jelasnya kita perhatikan table berikut:

\begin{tabular}{|l|l|l|l|}
\hline \multicolumn{1}{|c|}{ Afiksasi } & Bahasa arab & \multicolumn{1}{c|}{$\begin{array}{c}\text { Bahasa } \\
\text { Indonesia }\end{array}$} & Keterangan \\
\hline Prefix & $\begin{array}{l}\text { Kataba - } \\
\text { yaktubu }\end{array}$ & $\begin{array}{l}\text { Baca - } \\
\text { membaca }\end{array}$ & \\
\hline Infiks & $\begin{array}{l}\text { Kataba- } \\
\text { kaataba }\end{array}$ & Kerja-kinerja & \\
\hline Sufiks & $\begin{array}{l}\text { Kaatib- } \\
\text { kaatibah }\end{array}$ & Baca-bacaan & \\
\hline konfiks & $\begin{array}{l}\text { Kataba- } \\
\text { yaktubuuna }\end{array}$ & $\begin{array}{l}\text { Laku- } \\
\text { melakukan }\end{array}$ & \\
\hline
\end{tabular}




\section{Kesimpulan}

Dari berbagai pengertian yang ada bisa kita ambil kesimpulan bahwa yang dimaksud dengan infleksi adalah proses morfologis yang mneghasilkan bentuk kata yang berbeda, namun berasal dari leksem yang sama dan bentukan kata tersebut berada dalam kelas kata yang sama pula. Kata-kata dalam bahasa-bahasa berfleksi, seperti bahasa Arab, bahasa latin,maupun bahasa Indonesia dan bahasa Sansekerta, untuk dapat digunakan dalam kalimat harus disesuaikan dulu bentuknya dengan kategorikategori gramatikal yang berlaku dalam bahasa itu. Pada umumnya perubahan bentuk atau proses morfologi ini hanya menyatakan hubungan sintaksis dan tidak membawa pemindahan dari satu kelas kata kedalam kelas kata yang lainya. Pada masingmasing bahasa memiliki sistem yang berbeda, sesuai dengan bahasa itu sendiri, begitupula dengan bahasa arab dan bahasa Indonesia. Mereka memiliki sistem yang berbeda terutama dalam hal infleksi. dari uraian makalah diatas terdapat beberapa perbedaan dan juga persamaan antara kedua bahasa tersebut dalam proses infleksinya. Bahasa Arab lebih kuat terjadi infleksi dibanding dengan bahasa Indonesia. Akan tetapi selain ada perbedaan adapula persamaan antara keduanya. Dalam letak afiksasi bahasa Arab dan bahasa Indonesia sama-sama mengalami afiksasi baik dalam prefix, infiks, sufiks, maupun konfiks. 
Mimi Jamilah : Analisis Kontrastif Morfologi Infleksi dalam Bahasa Arab dengan

Bahasa Indonesia

\section{Daftar Pustaka}

Al-Ghalayani Musthafa 1972 .Jami' Al-Durus Al-Aarabiyah libanon: Al-Maktabah Al-Ashriyah

Ali Al khulli Muhammad 1982. Dictionary Of Theoretical Linguistic libanon: librarie du liban Ba'dulu, dkk. 2005. Morfosintaksis. Jakarta: Rineka Cipta.

Chaer Abdul 2007. Linguistik Umum jakarta:Rineka Cipta

H.P Achmad, Abdullah Alek 2013. Linguistik umum Jakarta: penerbit Erlangga

Harimurti Kridalaksana,. 2009. Kamus Linguistik. Jakarta: PT Gramedia, hlm:

J.W.M. Verhar. 1990 Asas-Asas Linguistik Umum Yogyakarta: Gajah Mada Press

J.w.M. Verhaan,1983. Pengantar Linguistik. Yogyakarta: GADJAH MADA UNIVERSITY PRESS

Muslih, Masnur 2010 .Tata Bentuk Bahasa Indonesia Jakarta: Bumi Aksara

Parera Jos Danil 1994 .Morfologi Bahasa Jakarta: Gramedia Pustaka

Perkuliahan Mata kuliyah Al-Falasafah Al-Lughowiyah UIN SUNAN AMPEL Surabaya

Sudaryanto, 2002. Metode Linguistik Yogyakarta: Gajah Mada Press, 